\title{
Dyskusja i spory wokół wprowadzania podwójnych nazw miejscowości na terenie Śląska Opolskiego
}

\section{Uwagi wprowadzające}

$\mathbf{N}^{2}$ a podstawie danych Głównego Urzędu Statystycznego z dnia 8 marca 2012 roku w Polsce, w 43 gminach województwa opolskiego, śląskiego, pomorskiego, warmińsko-mazurskiego i małopolskiego, 798 miast, wsi, osad i przysiółków posiada podwójne nazwy, z czego najwięcej bo 28 gmin, to gminy z polsko-niemieckimi nazwami. Podwójne nazwy miejscowości na terenie województw opolskiego i śląskiego wywołują najwięcej emocji, gdyż uderzają w jeden z najtrwalszych mitów polskich, mit na temat niekwestionowanej polskości ludności rodzimej Górnego Śląska. Nie odnosząc się do prawdziwości tego mitu, gdyż nie jest to celem tego artykułu, chciałbym jednak podkreślić, że gminy górnośląskie, w których wprowadzono podwójne nazwy znajdują się na obszarach, na których podczas plebiscytu z 20 marca 1921 roku oddano najwięcej głosów za przyłączeniem Górnego Śląska do Polski. Warto, aby świadomość tego faktu miały wszystkie strony sporu wokół problematyki tego artykułu. Uzmysłowienie tego wyniku powinno zwolennikom wprowadzania podwójnych nazw przypomnieć, że „opcja polska" nie pojawiła się po roku 1945 znikąd. Natomiast przeciwnicy powinni pokusić się o refleksję, dlaczego po 68 latach potomkowie tych, którzy w plebiscycie głosowali „za Polską” wybrali niemiecką opcję narodową.

Celem, jaki stawiam sobie w tym artykule jest poszukiwanie odpowiedzi na pytanie, na ile wprowadzenie w życie zapisów ustawy o mniejszościach narodowych i etnicznych oraz języku regionalnym z dnia 6 stycznia 2005 roku może przyczynić się do eskalacji konfliktu narodowościowego na Górnym Śląsku, zwłaszcza na terenie opolskiej części tego regionu, a na ile może być szansą na wypromowanie „Śląska Opolskiego" jako regionu, w którym Rzeczpospolita Polska w sposób modelowy realizuje europejskie standardy w tym zakresie? Jednak należy zauważyć, że istniejące europejskie regulacje w tej kwestii nie są jednoznaczne i unikają precyzyjnego określania kryteriów, spełnienie których powinno skutkować konieczność wprowadzenia podwójnych nazw ${ }^{2}$. Jak się wydaje brak jednoznacznych zapisów ma pozwolić

\footnotetext{
${ }^{1}$ Świadomie zastosowałem cudzysłów przy nazwie tego regionu, gdyż jest to nazwa sztuczna, niemająca jakiegokolwiek uzasadnienia historycznego czy kulturowego. W moim przekonaniu zjawiska, które występują na terenie wschodniej i zachodniej części Górnego Śląska doprowadzą w perspektywie najbliższych dwudziestu lat do przywrócenia status quo ante, a więc powstania jednego regionu pod nazwą Górny Śląsk. Z tego względu w dalszej części tego artykułu będę używał określenia opolski Górny Śląsk.

${ }^{2}$ Kwestia ta regulowana jest przez zapisy Konwencji ramowej o Ochronie Mniejszości Narodowych Rady Europy, nie jest to jednak część prawa wspólnotowego. W art. 10 ust. 2 tego dokumentu czytamy: Na obszarach zamieszkałych tradycyjnie lub w znaczacej ilości przez osoby należace do mniejszości narodowej, o ile osoby te tego sobie zażyczq, i tam, gdzie takie życzenie odpowiada rzeczywistym potrzebom, Strony będa starać się zapewnić, na tyle, na ile to możliwe, warunki, które umożliwiq używanie języka mniejszości w stosunkach pomiędzy tymi osobami a orga-
} 
„państwom zorientowanym narodowo” i „mniejszościom etnicznym” najlepiej w porozumieniu z „zagranicznymi ojczyznami” znaleźć kompromisowe rozwiązania w prawie krajowym i praktyce współżycia mniejszości z większością. Niestety jak pokazuje praktyka, np. współpracy na tym polu między mniejszością polską na Litwie a państwem litewskim i państwem polskim nie zawsze zawarcie takiego porozumienia jest możliwe.

\section{Podwójne nazwy miejscowości elementem procesu budowania tożsamości regionalnej}

Problematyka tego artykułu wpisuje się w nurt rozważań na temat tworzenia się tożsamości regionalnej („ojczyzny regionalnej” odwołując się do pojęcia, które wprowadził do socjologii St. Ossowski w połowie lat 40 ubiegłego wieku) na Ziemiach Zachodnich i Północnych. Proces ten przebiega najbardziej spektakularnie na obszarze Górnego Śląska. Jednym z jego przejawów było i nadal jest, dążenie do powrotu do niemieckich nazw miejscowości, co stało się możliwe po uchwaleniu przez parlament polski tzw. „ustawy mniejszościowej”. Jednak aby zrozumieć złożoność tego procesu należy poczynić kilka uwag wprowadzających, bez których trudno byłoby wyjaśnić istotę sporów i kontrowersji a często i konfliktów ${ }^{3}$, jakie wprowadzanie zapisów tej ustawy wywołuje.

Początki polityki wykorzystywania na Górnym Śląsku nazw topograficznych w walce o dominację kulturową sięgają momentu przyłączenia Śląska do Prus a więc połowy XVIII wieku, kiedy to na teren Śląska zaczęła napływać ludność niemiecka w ramach kolonizacji fryderycjańskiej. Jednak o zmianie nazw i pojawieniu się na Śląsku nazw w językach narodów, które nad tym obszarem dominowały politycznie i kulturowo można mówić już od okresu średniowiecza, lecz jako oręż walki o dominację kulturową problem ten z całą mocą pojawił się w drugiej połowie XIX wieku, kiedy to Europa definiowała swoje granice w oparciu o kryteria etniczne.

Przybywający na teren Śląska osadnicy niemieccy przynosili do swojej nowej ojczyzny oprócz dobytku materialnego również tożsamość kulturową, która kształtowała miejsce ich przybycia również poprzez nadawanie „,swoich” nazw miejscom, na których się znaleźli. Jednak na obszarach, na których zetknęli się oni z ludnością autochtoniczną dochodziło najczęściej do dyfuzji kulturowej, efektem której było zastępowanie nazw zastanych swoimi, bądź asymilowanie nazw swoich do nazw zastanych. W efekcie wśród ślaskich nazw miejscowych spotykamy m.in. nazwy będace rezultatem adaptacji nazw słowiańskich do systemu nazewnictwa niemieckiego i nazwy powstałe na gruncie języka polskiego w wyniku adaptacji do niego

nami administracyjnymi; i dalej w art. 11 ust. 3: W rejonach tradycyjnie zamieszkałych przez znaczqcq ilość osób należacych do mniejszości narodowej Strony będq starać się - zgodnie z obowiqzujacym prawem, w tym także, tam gdzie to stosowne, umowami z innymi państwami oraz przy uwzględnieniu ich specyficznych warunków - umieszczać również w języku mniejszości tradycyjne nazwy lokalne, nazwy ulic i inne oznakowania topograficzne o charakterze publicznym, o ile istnieje tam wystarczajace zapotrzebowanie na takie oznakowania, w: L. M. Nijakowski, Domeny symboliczne. Konflikty narodowe i etniczne w wymiarze symbolicznym, Warszawa 2006, s. 178.

${ }^{3} \mathrm{Na} 8$ maja (sic!) 2013 roku działacze Prawa i Sprawiedliwości w Opolu planują w Opolu marsz pod nazwą,,Tu jest Polska", którego celem jest przeciwstawienie się rosnącym, ich zdaniem, wpływom mniejszości niemieckiej oraz umacnianiu się na całym Górnym Śląsku pozycji Ruchu Autonomii Śląska. W przekonaniu działaczy tej partii, wspieranej przez członków Obozu Narodowo-Radyklanego: Jeśli nie podejmie się czegoś przeciw Niemcom i separatystom na Ślasku, powstanie tam drugie Kosowo albo sytuacja jak w kraju Basków, K. Kandzia, Drugie Kosowo, „Wochenblatt.pl” z dnia 14-20 grudnia 2012 r. 
niemieckich elementów nazewniczych. Proces ten przebiegat dwutorowo. Z jednej strony przejmowanie i przyswajanie nazw z jednego języka do drugiego mogło odbywać się spontanicznie, droga bezpośrednich kontaktów dwóch różnych grup etnicznych żyjacych w symbiozie językowej. Z drugiej zaś, występowała adaptacja oficjalna, odgórna, w wyniku której obcym nazwom w sposób świadomy $i$ zamierzony nadawano formy oraz brzmienie odpowiadajace obowiazujacemu językowi urzędowemu ${ }^{4}$.

Jednak wpływ na stosunki etniczne na Górnym Śląsku poprzez wprowadzanie „swoich” nazw było wykorzystywane nie tylko przez stronę niemiecką. Z podobną sytuacją mieliśmy do czynienia, zwłaszcza po II wojnie światowej, na całym obszarze „ziem odzyskanych”. Ustalanie nazw miejscowości było pochodną propagandowego (mobilizującego) hasła myśmy tutaj nie przybyli, myśmy tutaj wrócili. Konsekwencją przyjęcia tego założenia było wydobywanie słowiańskości, która wówczas była jednoznacznie identyfikowana z polskością tych ziem. Dla realizatorów akcji przywracania polskości ziemiom zachodnim kamienie milczały po polsku. Proces przywracania polskości poprzez przywracanie słowiańskich nazw topografícznych szczególnie intensywnie przebiegał na obszarze Górnego Śląska, gdyż połączony był również z przywracaniem narodowi polskiemu zgermanizowanej ludności polskiej. Od samego początku udział Górnoślazaków w tym procesie był ograniczony z przyczyn obiektywnych (nowe władze nie miały do tej ludności zaufania z uwagi na przyjętą przez Górnoślązaków postawę w czasie II wojny światowej, kiedy to wielu z nich podpisało Volkslistę) oraz subiektywnych (niemal natychmiast po zakończeniu wojny pojawiło się ,,prawo tła"5). W konsekwencji po 45 latach na terenie opolskiej części Górnego Śląska część jego mieszkańców twierdziła, że dla nich na Górnym Śląsku die Steine schweigen Deutsch. Paradoksalnie zdarzało się często, że były to te same kamienie, które niegdyś milczały po polsku.

Po zakończeniu I wojny światowej doszło do ukształtowania się granicy polsko-niemieckiej na Górnym Śląsku. W tej jego części, która pozostała w granicach niemieckich niemal od samego początku dochodziło do zmian nazw zbyt słowiańsko (nieniemiecko) brzmiących co zdaniem animatorów tego procesu zbyt wyraźnie świadczyło o jego polskiej (słowiańskiej) przeszłości. Była to zapowiedź procesu, który przyjął najbardziej drastyczną formę w latach 1933-1938. Okres ten można podzielić na dwa podokresy. Pierwsza fala germanizacji krajobrazu semantycznego miała miejsce w latach 1933-1935, druga przypadła na lata 1936-1938. W obu tych „falach” zmieniono na „niemieckim” Górnym Śląsku 1120 nazw miejscowości i 660 nazw topograficznych. Przykłady tych zmian: Polsnisch Neukirch na Gross Neukirch, Polnisch Neudorf na Neudorf, Polnisch Wette na Wette. W czasie sprawowania władzy przez narodowych socjalistów zmiany poszły w kierunku jeszcze większych przekształceń mających podkreślać niemiecki charakter prowincji Ober-Schlesien, przykłady: Königlich Dombrowka na Eichendorf, Polnisch Würbitz na Oberweiden, Dombrowka na Eichtal, Sucho-Danietz na Trockenfeld ${ }^{6}$. Pojawienie się nazw z tego drugiego podokresu jest źródłem

\footnotetext{
${ }^{4}$ M. Choroś, Ł. Jarczak, Niemieckie elementy w nazwach miejscowych, w: Wokół niemieckiego dziedzictwa kulturowego na Ziemiach Zachodnich i Pólnocnych, red. Zb. Mazur, Poznań 1997, s. 418.

${ }^{5}$ Stanisław Ossowski, w raporcie z badań nad ludnością autochtoniczną prowadzonych przez niego i Jana Strzeleckiego w sierpniu 1945 w podopolskiej wsi Dobrzeń Wielki (w książce nazwanej Giełczynem) pisze: [...] obcowanie z repatriantami osłabiło Ślazakom poczucie dystansu społecznego względem Niemców, sprawiło, że Niemcy we wspomnieniach poczęli ukazywać się jako ludzie tej samej kultury, jako bardziej swoi niż te „,Poloki” mówiqce z ukraińska, nazywajace Śląaków Niemcami, St. Ossowski, O ojczyźnie i narodzie, rozdział: Zagadnienia więzi regionalnej $i$ więzi narodowej, Warszawa 1984, s. 112

${ }^{6}$ M. Wagińska-Marzec, Spory o nazwy miejscowości na Opolszczyźnie jako syndrom walki o tradycję, ,Zeszyty Instytutu Zachodniego" 2002, nr 27, Poznań 2002, s. 7-8.
} 
sporów, jakie miały miejsce przy okazji dyskusji na temat tego do jakich nazw miejscowości należy odwoływać się? Konflikty dotyczące tego pytania pojawiły się niemal natychmiast po roku 1989, a szczególnie intensywnie dały o sobie znać przy okazji wprowadzania zapisów „ustawy mniejszościowej” po roku 2005.

Konflikt wywołał przede wszystkim fakt, że po roku 1989 liderzy mniejszości niemieckiej często wskazywali na te nazwy jako nazwy historyczne, które zamierzali wprowadzić. Trudno było oczekiwać innej niż niechętna reakcja na te postulaty ze strony zarówno polskich mieszkańców miejscowości, które spełniały zapisy ustawy o zamieszkiwaniu w nich przynajmniej 20\% ludności stanowiącej mniejszość narodową, jak i nacjonalistycznych środowisk w Polsce w ogóle 7 . Formułowano wręcz zarzuty o ,zagrożeniu niemieckim”, o „utracie suwerenności” państwa polskiego nad tą częścią Górnego Śląska, która jest zdominowana przez ludność autochtoniczną deklarującą swoje niemieckie pochodzenie. Najbardziej spektakularny przykład, to sytuacja w gminie Bierawa, w której mieszkańcy wsi Kotlarnia jako wyraz sprzeciwu wobec faktu, że większość radnych tej gminy to przedstawiciele mniejszości niemieckiej, złożyli wniosek o zarejestrowanie Stowarzyszenie Mniejszości Polskiej. Był to swoisty opór wobec wprowadzenia języka niemieckiego jako języka ojczystego w miejscowej szkole. Aktualnie wydaje się, że intensywność konfliktu uległa wyciszeniu, nie oznacza to jednak, że nie będzie się on pojawiał przy okazji wprowadzania kolejnych zapisów „ustawy mniejszościowej”, a więc w trakcie wprowadzania podwójnych nazw ulic czy egzekwowania zapisów ustawy o obsłudze mieszkańców w języku mniejszości.

\section{Znaczenie nazw w dialogu międzyetnicznym}

Nazwy topograficzne, obok języka, są najważniejszym wytworem kulturowym, do którego odwołują się zbiorowości w definiowaniu swojej tożsamości. Potrzeba tego typu definicji pojawiła się wraz z odejściem homogenizującego wszelkie przejawy życia społecznego sytemu. Zmiana systemu politycznego doprowadziła do pojawienia się tendencji odwrotnej, której najbardziej spektakularnym przejawem była i jest dyskusja na temat regionalizmu i jednego z jego odmian, czyli regionalizacji ${ }^{8}$. Szczególne nasilenie tej dyskusji miało miejsce w latach 90. ubiegłego wieku podczas wypracowywania koncepcji dotyczących kształtu reformy administracyjnej. Ziemie Zachodnie i Północne, do których zalicza się opolski Górny Śląsk, z uwagi na fakt, że jako polskie regiony powstały po 1945 roku, a do roku 1989 nie mogły w jakiś szczególny sposób odwoływać się do swojej odrębności, w dyskusji tej podnosiły głównie problem definiowania tożsamości regionalnej w oparciu o kryteria gospodarcze, administracyjne i częściowo kulturowe. Na terenie opolskiego Górnego Śląska mamy do czynienia z sytuacją szczególną, gdyż jego wschodnią część zamieszkuje ludność rodzima, która po roku 1989 w większości wybrała niemiecką opcję narodową, a tym samym podkreśliła

\footnotetext{
${ }^{7}$ Policja twierdzi, że większość aktów wandalizmu związanych z zamalowywaniem niemieckich nazw miejscowości w województwie opolskim dopuszczają się przedstawiciele nacjonalistycznych środowisk spoza tego województwa a już zdecydowanie najrzadziej przejawów takiej agresji symbolicznej dopuszczają się mieszkańcy tych miejscowości, w których występują podwójne nazwy.

${ }^{8}$ Proponuję, aby regionalizm rozumieć jako proces zmierzający do organizowania się społeczności lokalnych w obrębie naturalnych regionów lub ruch w kierunku budowy wspólnot regionalnych i subregionalnych, których członkowie są złączeni historycznymi więzami, wynikającymi z przynależności do mniejszych grup powiązanych wspólną przestrzenią geograficzną. Z kolei regionalizacja to eksponowanie różnic głównie kulturowych w celu realizacji aspiracji politycznych związanych z autonomią czy separatyzmem.
} 
swoją odrębność względem narodu polskiego. Odrębność ta przejawiała się początkowo w wyborze niemieckiej opcji narodowej, lecz aktualnie można zaobserwować wzmacnianie się tendencji do wyboru swojej śląskości jako kategorii pośredniej między polskością a niemieckością. W procesie tym opolscy Górnoślazacy „,spotykają” się z Górnoślązakami „katowickimi”. Można wręcz pokusić się o sformułowanie tezy, że po 90. latach rozdzielenia, z przerwą na okres drugiej wojny światowej, Górny Śląsk się jednoczy, a przynajmniej nastały sprzyjające warunki do tego, aby do takiego zjednoczenia mogło dojść. Oczywiście z uwagi na interesy głównie polityczne liderom ruchu mniejszości niemieckiej nie zależy na akcentowaniu wspólnoty kulturowej z Górnoslazakami z województwa śląskiego, lecz to, że owa wspólnota jest faktem obiektywnym prowadzi do zbliżania tych dwóch grup ${ }^{9}$. W latach 1945 (1950)-1989 na Górnym Śląsku utrzymano podział ukształtowany po I wojnie światowej kiedy to region ten został podzielony na wschodnią część (autonomiczne województwo śląskie) i część zachodnią (Ober-Schlesien). Reforma administracyjna z roku 1998 utrzymała ten podział. Jeśli wspominam o możliwości ,zjednoczenia” na podstawie kryterium, jakim jest terytorium Górnoślązaków poprzez osiągnięcie stanu sprzed 1922 roku, to wynika z konieczności uwzględnienia wyników spisu powszechnego z roku 2011, które pokazują konwersję w definiowaniu swojej przynależności etnicznej u ludności rodzimej województwa opolskiego. Jest to część szerszego zjawiska, z którą spotykamy się na Górnym Śląsku, a mianowicie artykułowania przez Górnoślazaków przynależności do narodu śląskiego. Podczas spisu ludności z 2011 roku 847 tys. osób wskazało na swoją przynależność do narodu śląskiego, głównie są to mieszkańcy województwa śląskiego. Z kolei spośród 126 tys. osób, które wskazały swoją niemiecką przynależność narodową, zdecydowana większość zamieszkuje województwo opolskie. Łącznie więc około 950 tys. mieszkańców Górnego Śląska w jego historycznych granicach, w taki czy inny sposób, zakwestionowało twierdzenie, że każdy Górnoślązak to Polak. Intensywność tego dystansowania się była różna dla tych, którzy wybrali niemiecką opcję narodową (148 tys.), inna dla tych którzy wybrali opcję śląską jako jedyną (376 tys. osób), a inna dla tych, którzy wskazywali identyfikację śląską łącznie z polską (431 tys. osób) $)^{10}$.

Jeśli przyjąć, że na terenie obu tych województw mieszka około 1,5-1,7 mln Górnoślązaków spełniających kryteria ustawy o mniejszościach etnicznych i narodowych pozwalających ich zaliczyć nominalnie do odrębnego narodu, to jest to liczba znacząca. Ważniejszy jest jednak znaczący, bo prawie pięciokrotny w stosunku do roku 2002, wzrost liczby mieszkańców Górnego Śląska, którzy podczas spisu powszechnego z wiosny 2011 wskazało na swoje górnośląskie pochodzenie. Ignorowanie tego zjawiska, poprzez przemilczanie, bądź wskazywanie szybkich odpowiedzi, w stylu kieruje nimi koniunkturalizm, chęć osiagnięcia doraźnych celów politycznych, za aspiracjami tymi kryją interesy lokalnych elit politycznych, które nie znalazły dla siebie miejsca w głównym nurcie polskiego życia politycznego, choć jest w części prawdziwe, to jednak byłoby co najmniej spłyceniem problemu i nie przybliżyłoby do znalezienia odpowiedzi na pytanie o przyczyny tego zjawiska. Dążenie do tego, aby na obszarach

\footnotetext{
${ }^{9} \mathrm{Na}$ początku lat 90. kiedy mniejszość niemiecka organizowała się ok. 300 tys. mieszkańców województwa opolskiego wskazało na swoje niemieckie pochodzenie, podczas narodowego spisu ludności, który przeprowadzono w roku 2002156 tys., a podczas spisu z roku 2011 liczba ta nieco spadła do 148 tys. natomiast wzrosła liczba mieszkańców województwa opolskiego, która wskazała na swoją śląską przynależność narodową.

${ }^{10}$ Dane za: Przynależność narodowo-etniczna ludności-wyniki spisu ludności i mieszkań 2011, Notatka informacyjna GUS, 29.01.2013. Są to na chwilę obecną najbardziej aktualnie wyniki spisu dotyczące przynależności etnicznej i narodowej obywateli Polski. Badacze nadal oczekują na prezentację wyników dotyczących tej przynależności analizowanej na poziomie gmin.
} 
zamieszkiwanych przez mniejszości narodowe stosowano podwójne nazwy jest oczywistym przejawem dystansowania się części Górnoślązaków od narodu polskiego.

W „Zeszycie Instytutu Zachodniego” nr 27/2002 jego autorka stwierdza, że dążenie do zachowania nazw topograficznych $\mathrm{w}$ tym przypadku $\mathrm{w}$ języku niemieckim jest jednym z najważniejszych przejawów dążenia do zachowania własnej tożsamości ${ }^{11}$. Słusznie więc zauważa ona, że chodzi o zachowanie, a nie definiowanie swojej tożsamości, jak w przypadku pozostałych obszarów, które swoim zasięgiem obejmuje pojęcie Ziemie Zachodnie i Północne.

\section{Historia ustawy}

Problem podwójnych nazw miejscowości pojawił się niemal od samego początku, jako główny postulat przedstawicieli mniejszości niemieckiej na Śląsku Opolskim po roku 1989. Miał to być najbardziej widoczny znak tego, że na Śląsku Opolskim obok ludności polskiej o różnym pochodzeniu mieszka ludność niemiecka. Stało się to możliwe dzięki przyjętej przez Sejm RP w dniu 6 stycznia 2005 Ustawie o mniejszościach narodowych i etnicznych i języku regionalnym, która zaczęła obowiązywać w dniu 1 maja 2005, a więc w rok po przystapieniu Polski do Unii Europejskiej. Ta uwaga jest o tyle istotna, że przedstawiciele mniejszości narodowych i etnicznych od samego początku mocno podkreślali to, że przystąpienie Polski do Unii Europejskiej wymusi na Polsce przyjęcie „ustawy o mniejszościach”. W swoim artykule odwołuję się do oczekiwań wobec „ustawy” formułowanych głównie przez środowisko mniejszości niemieckiej skupione wokół tygodnika „Schlesisches Wochenblatt” (od stycznia 2011 „Wochenblatt.pl”), który od początku swego istnienia był swego rodzaju organem prasowym środowiska mniejszości niemieckiej z terenu Śląska Opolskiego.

Prace nad ustawą, która jest swoistym testamentem Jacka Kuronia, długoletniego przewodniczącego sejmowej Komisji Mniejszości Narodowych i Etnicznych, rozpoczęły się już w roku 1989. Jej projekt powstawał przez kilka lat z uwagi na fakt, że przyjęcie tej ustawy kwestionowało przekonanie na temat Polski, jako kraju jednolitego etnicznie i narodowo, co szczególnie trudne było do zaakceptowania dla części prawej strony polskiej sceny politycznej.

W sierpniu 1989 w Sejmie Rzeczpospolitej Polskiej po raz pierwszy, od czasu zakończenia II wojny światowej, powołano komisję ds. mniejszości narodowych. Jej zadaniem było opracowanie projektu ustawy. W kolejnych kadencjach parlamentu w komisji tej powstały trzy projekty, ale żadnego nie udało się uchwalić. Dopiero na początku 2005 roku Sejm RP uchwalił długo oczekiwaną przez mniejszości ustawę. Szczególnie wiele kontrowersji wywołały artykuły 9 i 10, które umożliwiały mniejszościom wprowadzanie na terenie gmin gdzie stanowią oni przynajmniej 20\% mieszkańców podwójnych nazw miejscowości i nazw topograficznych, posługiwanie się ich językiem w urzędach. Posłowie zdecydowali o podniesieniu tego progu do 50\% i przyjęli projekt ustawy w dniu 4 listopada 2004 roku. W trakcie głosowania 247 posłów było za, 133 przeciw, 6 wstrzymało się od głosu. Po uwzględnieniu poprawek Senatu RP, dzięki którym próg ponownie zmniejszono do $20 \%$, ustawa o mniejszościach została ostatecznie uchwalona 6 stycznia 2005 roku. W dniu 7 stycznia 2005 roku „Ustawa o mniejszościach narodowych i etnicznych i języku regionalnym” została przekazana prezydentowi Aleksandrowi Kwaśniewskiemu do podpisu. Jak się wydaje był to ostatni

${ }^{11}$ M. Wagińska-Marzec, Spory o nazwy..., op. cit., s. 5. 
moment, w którym ustawa ta mogła być przyjęta, gdyż zmiany na polskiej scenie politycznej zapoczątkowane wynikami wyborów parlamentarnych i prezydenckich z jesieni 2005 zapewne utrudniłyby przyjęcie przez sejm i senat tej ustawy.

Punktem wyjścia dla zapisów ustawy były wyniki przeprowadzonego Narodowego Spisu Powszechnego z roku 2002, który wykazał, że na terenie Rzeczypospolitej Polskiej 471475 osób zadeklarowało narodowość niepolską.

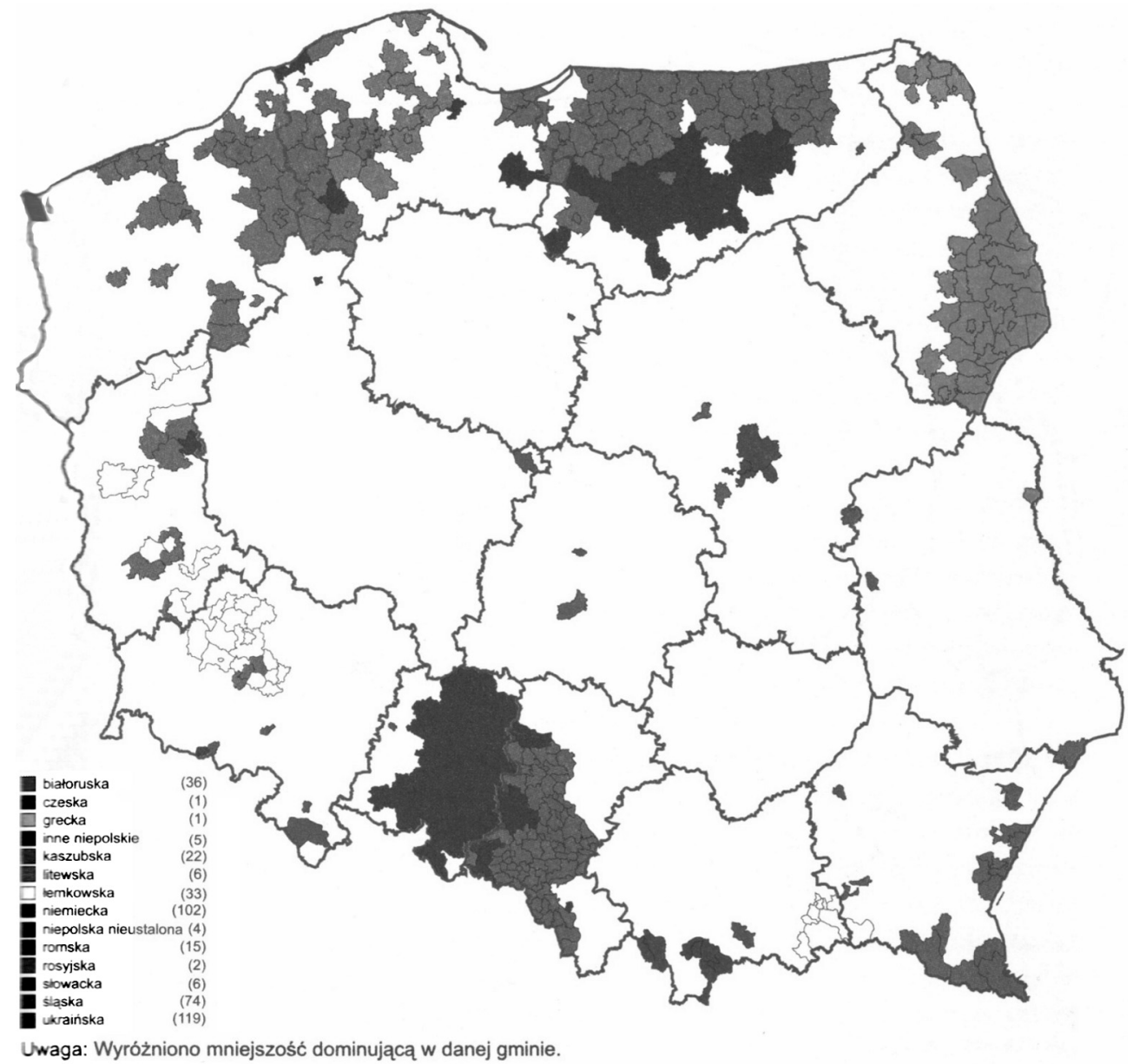

Mapa 1. Rozmieszczenie grup narodowych i etnicznych w Polsce wg Narodowego Spisu Powszechnego z $2002 \mathrm{r}$.

Źródło: K. Szczygielski, Geografia mniejszości narodowych i etnicznych w Polsce. Ujęcie ilościowe, Opole 2006.

Robert Radziński omawiając wyniki spisu w obszarze dotyczącym składu etnicznego ludności polskiej, zwracał uwagę na to, że w trakcie spisu około $2 \%$ populacji nie zostało nim objęte najczęściej $\mathrm{z}$ uwagi na nieobecność $\mathrm{w}$ miejscu zamieszkania $\mathrm{w}$ trakcie spisu ${ }^{12}$. Jak

${ }^{12}$ R. Radziński, K. Szczygielski, Ślaska ludność rodzima w strukturze demograficznej i społecznej Ślaska Opolskiego wczoraj i dziś, Opole 2008, s. 11. 
wiadomo problem stałego przebywania obywateli polskich poza granicami państwa polskiego dotyczy głównie mieszkańców województwa opolskiego, z którego wielu mieszkańców pochodzenia niemieckiego na stałe przebywa na terenie Republiki Federalnej Niemiec. Stąd można z dużym prawdopodobieństwem założyć, że liczba osób deklarujących przede wszystkim niemieckie pochodzenia byłaby wyższa. Na podstawie danych pochodzących ze spisu należy stwierdzić, że 1,23\% obywateli państwa polskiego to mniejszości narodowe i etniczne. Jednak, uwzględniając ,nieobecnych” liczba ta oscylowałaby wokół 1,2\% do najwyżej 3\%. W świetle wyników spisu powszechnego liczba gmin, które spełniły warunki sformułowane w artykułach 9, 10 i 12 ustawy o mniejszościach narodowych i etnicznych i języku regionalnym wynosi 51, z czego 41, to gminy z wymaganym ustawowo udziałem $20 \%$ i więcej osób deklarujących niepolską przynależność narodową oraz 10 gmin, dla których ustalono zamieszkanie $20 \%$ i więcej osób posługujących się językiem regionalnym (kaszubskim).

Na terenie województwa opolskiego gmin zamieszkałych przez ludność deklarującą swoje niemieckie pochodzenie jest 27, na terenie województwa śląskiego 1. Pozostałe gminy znajdują się na terenie województw podlaskiego (12 „,białoruskich” i 1 ,litewska”) i pomorskim (10 gmin ,kaszubskich”).

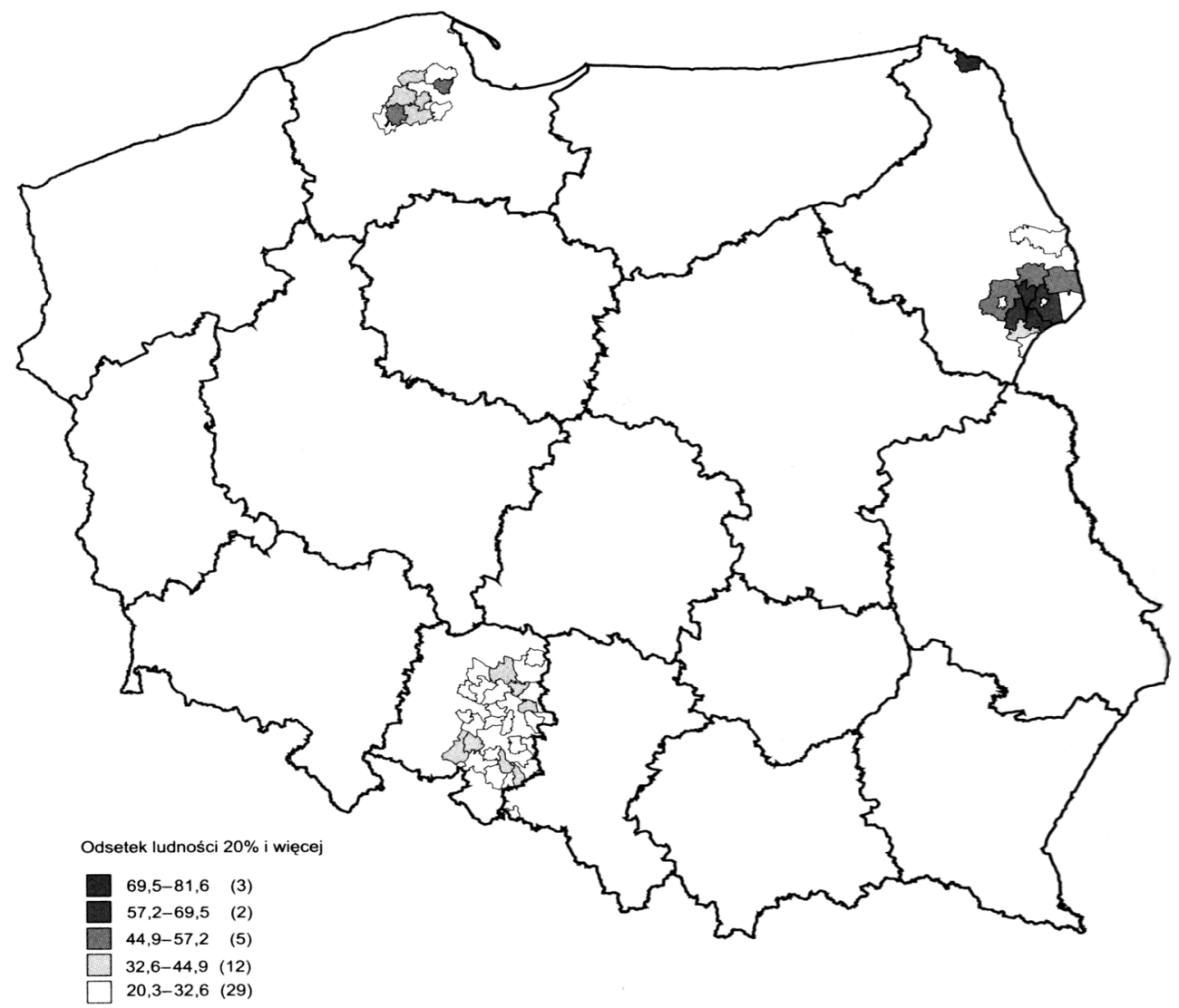

Mapa 2. Mniejszości narodowe i etniczne oraz ludność posługująca się językiem regionalnym w Polsce w 2002 r. wg wymogów ustawy

Źródło: K. Szczygielski, Geografia mniejszości narodowych i etnicznych w Polsce. Ujęcie ilościowe, Opole 2006. 
W ocenie liderów organizacji mniejszości niemieckiej przyjęcie przez Sejm Rzeczypospolitej Polskiej ustawy, to nic innego jak przyznanie się Polski do wieloetniczności, tak komentował ten fakt wieloletni redaktor naczelny tygodnika „Schlesisches Wochenblatt” Engelbert $\mathrm{Mis}^{13}$.

W trakcie dyskusji na temat konieczności wprowadzenia ustawy w życie panowało przekonanie, że:

a) ureguluje ona sprawy dwujęzyczności na terenach zamieszkałych przez mniejszości etniczne i narodowe;

b) wprowadzi jasne definicje tego, czym jest mniejszość etniczna i narodowa;

c) wymieni występujące w Polsce mniejszości etniczne i narodowe.

Od samego początku zarówno politycy, jak przedstawiciele mniejszości, najwięksi zwolennicy ustawy, zdawali sobie sprawę z tego, że może być ona źródłem napięć na terenie gmin zamieszkałych przez mniejszości.

\section{Wprowadzanie w życie zapisów ustawy}

Z uwagi na powyższe obawy od samego początku przyjęto założenie, aby wprowadzanie postanowień ustawy dotyczących podwójnych nazw miejscowości, jak i używania języka mniejszości, jako języka pomocniczego wywoływało jak najmniej kontrowersji i nie było zarzewiem konfliktu narodowościowego. Szczególnie chodziło o polskich mieszkańców tych gmin, którzy teoretycznie mogli być nastawiani niechętnie do tej zmiany. Dlatego od samego początku przyjęto zasadę nic na siłę ${ }^{14}$, wprowadzanie podwójnych nazw miejscowości poprzedzano zazwyczaj konsultacjami z mieszkańcami gmin ${ }^{15}$, w których tablice te miały się pojawić. W stosunku do innych regionów Polski, w których spełnione były warunki ustawy, sytuacja na Śląsku Opolskim była wyraźnie odmienna. O ile na Kaszubach odmienność tej ludności była znana i akceptowana w społeczeństwie polskim nawet przed rokiem 1989, podobnie było z ludnością białoruską na białostocczyźnie, o tyle na Śląsku Opolskim nie niemieckim mieszkańcom tego województwa trudno było zaakceptować kolejną fazę emancypowania się części mieszkańców ich regionu w kierunku niemieckości. W efekcie początkowo wprowadzanie ustawy o mniejszościach narodowych szło bardzo opornie. Z jednej strony samorządowcy obawiali się reakcji ich wyborców, nie chcąc się narazić na utratę popularności, z drugiej konfrontowani oni byli ze stereotypowym myśleniem na temat odmienności narodowej, która na terenach zamieszkałych przez mniejszość niemiecką musiała przybrać postać myślenia o niej, jako o ,piątej kolumnie”. Jak się wydaje do tej pory obowiązuje zasada niech: zajmą się tym urzędnicy, których jest to obowiązkiem. Dopiero, gdy zostaną oswojone

\footnotetext{
${ }^{13}$ E. Miś, Deutsch im Amt, ,Schlesisches Wochenblatt” z dnia 14-20 stycznia 2005 r.

${ }^{14}$ Burmistrz Krzanowic (niem. Kranowitz) Manfred Abrahamczyk zakładał, że żadnych nagłych zmian w gminie nie będzie. Nasze działania będq uzależnione od oczekiwań mieszkańców. Nie będziemy robili nic na hurra. Jeżeli pojawiq się wnioski, wtedy podejmiemy stosownq uchwałę w sprawie nazw dwujęzycznych; W. Dobrowolski, Ślub po niemiecku, „Schlesisches Wochenblatt” z dnia 21-27 stycznia 2005 r.

${ }^{15} \mathrm{~W}$ wypadku nazw fizjograficznych takich jak nazwy miejscowości, ulic, rzek itp., potrzebne sq konsultacje spoleczne. - Sq dwie opinie na ten temat-informuje wójt. - Jedni twierdzq, że z ustawy nie wynika wprost, iż potrzebne sq konsultacje społeczne. Z drugiej strony mamy sołectwa w gminie, w których mniejszość niemiecka nie osiagnęła 20 procent. Więc $w$ tych miejscowościach będziemy musieli przeprowadzić konsultacje społeczne. - Dla spokoju warto by ludzie się wypowiedzieli [podkr. C. T.]; W. Dobrowolski, Wójtowie bojq się dwujęzycznych tablic, ,Schlesisches Wochenblatt" z dnia 23 grudnia 2005 r.-5 stycznia 2006 r.
} 
niemieckie nazwy miejscowości przyjdzie czas na ulice i zakłady usługowe, instytucje kultury, instytucje państwowe, a na końcu na sferę prywatną, czyli na napisy na domach, wewnątrz tychże. W świetle wyników badań prowadzonych w maju 2005 roku stosunek społeczeństwa polskiego był dość niejednoznaczny, o ile była zgoda na nauczanie w szkołach języka mniejszości i prowadzenia zajęć w jej języku, o tyle nie było takowej zgody na wprowadzenia podwójnych nazw miejscowości na terenach zamieszkałych przez mniejszość. Interesujące ujęcie formułowali respondenci z wyższym wykształceniem i respondenci o niskim statusie materialnym. Jest to o tyle zastanawiające, że zmienne te w większości badań trudno się korelują ${ }^{16}$.

W dyskusji, jaka toczyła się i nadal się toczy wokół problemu dwujęzycznych tablic i języka mniejszości jako języka pomocniczego da się wyodrębnić dwojakiego rodzaju postawy. Pierwsza zawiera się w stwierdzeniu, nareszcie, tyle musieliśmy czekać na te tablice, druga postawa, a po co nam to, przecié jesteśmy w Polsce. W moim przekonaniu istota problemu polega na tym, że język niemiecki nie jest, ,językiem serca" (Muttersprache) dla mieszkańców Śląska Opolskiego deklarujących swoje niemieckie pochodzenie, językiem tym dla zdecydowanej większości z nich jest gwara śląska, która jest jednym z najważniejszych elementów identyfikacji kulturowej Ślązaków w ogóle, w tym Ślązaków ze Śląska Opolskiego ${ }^{17}$. Tak, więc wprowadzenie języka niemieckiego do użytku publicznego to proces, który trwał będzie wiele lat, o ile w ogóle do tego dojdzie. W zasadzie język ten jest jedynie używany przez najstarszych mieszkańców, którzy mieli możliwość nauczenia się go w niemieckiej szkole i posługiwania się nim w niemieckim państwie. Jednak i dla większości z nich był to „obcy”, którego nie mogą używać w komunikacji ze swoimi dziećmi a tym bardziej wnukami. Świadczy o tym spadająca z uwagi na liczbę uczestników liczba mszy odprawianych w języku niemieckim czy stosunkowo słaby nacisk na władze samorządowe, aby w szkołach zwiększano liczbę godzin nauczania języka niemieckiego czy tworzenia klas z językiem niemieckim jako językiem nauczania. Liderzy mniejszości niemieckiej w Polsce z zazdrością skonstatowali, że mniejszość polska na Litwie powszechnie używa języka polskiego w sytuacjach publicznych $^{18}$. Wśród uzasadnień istniejącego na Śląsku Opolskim stanu rzeczy przytacza się argumenty o dyskryminacji, która jest udziałem rodziców zmuszanych do deklaracji swojej przynależności narodowej i dzieci, które mają być szykanowane epitetami „Germańcy”"19 przez polskie dzieci. Wydaje się jednak, że istota problemu z językiem niemieckim wśród członków organizacji mniejszościowych polega na tym, że nie jest to ich język narodowy. Również w tym przypadku z dużym zainteresowaniem należy obserwować w jakim kierunku zmierzać będzie konwersja identyfikacji narodowej wśród Górnoślązaków. W moim przekonaniu

${ }^{16}$ M. Wagińska-Marzec, Postawy mieszkańców Opolszczyzny wobec podwójnych nazw miejscowości, Poznań 2003, s. 17.

${ }^{17}$ Patrz więcej na ten temat M. Szmeja, Niemcy? Polacy? Ślazacy!, Kraków 2000; A. Kłoskowska, Kultury narodowe u korzeni, Warszawa 1996.

${ }^{18}$ Bernardowi Gaidzie [prezydent Związku Niemieckich Stowarzyszeń Społeczno-Kulturalnych - przyp. C. T.] rzuciło się w oczy przede wszystkim to, że wszyscy ludzie żyjacy na terenach mniejszości polskiej wokół Wilna mówia po polsku. Nie zmieniła tego także litewska ustawa o języku państwowym z 1995 roku, która m.in. zabrania publicznego stosowania np. polskojęzycznych nazw ulic czy też polskiej pisowni nazwisk. - Miałem możliwość przebywania na imprezie kulturalnej zorganizowanej $w$ wiosce $40 \mathrm{~km}$ od Wilna, gdzie styszatem tylko $i$ wyłacznie język polski - stwierdzil niemal zazdrośnie. Wrażenie sprawiło na nim również polskie szkolnictwo: - Sa to szkoły publiczne finansowane wyłacznie ze środków litewskich; nauczanie jest zorganizowane całkowicie w języku polskim. Litewski jest nauczany jako język obcy. System szkolnictwa polskiego wywart na mnie wielkie wrażenie jako niezwykle profesjonalny i przemyślany; K. Kandzia, Alle sprechen Polnisch, „Schlesisches Wochenblatt” z dnia 6-12 sierpnia $2010 \mathrm{r}$.

${ }^{19}$ E. Miś, Quo vadis, mniejszości niemiecka w Polsce?, „Dialog” 2009, nr 87. 
będzie to zmiana w kierunku wyboru opcji najbardziej „,bezpiecznej”, bo niezmuszającej do jakiegokolwiek wysiłku i pozwalająca na zmianę tej identyfikacji w kierunku opcji wyrażającej się stwierdzeniem jestem Ślazakiem, jestem u siebie. Na rzecz takich przewidywań przemawia to, że liderzy mniejszości niemieckiej bez większego entuzjazmu podchodzą do ruchu na rzecz uznania Ślązaków za odrębny naród, używając określenia tak zwana mniejszość ślaska ${ }^{20}$. Wydawało się, że w pewnym sensie dla rozstrzygnięcia tego dylematu ważne będą między innymi wyniki spisu z 2011 roku, kiedy to mocno spierano się o treść pytań, które miały zostać zadane respondentom w taki sposób, aby jednocześnie (jeśli jest to w ogóle możliwe) rozstrzygnąć kwestię identyfikacji narodowej czy etnicznej pytanych.

Pierwszą gminą, która wprowadziła na swoim terenie podwójne nazwy miejscowości była gmina Radłów (niem. Radlau). Tablice z polskimi i niemieckimi nazwami miejscowości pojawiły się na terenie tej gminy 22 grudnia 1996 roku. W roku 2007 uczyniła to gmina Cisek (niem. Cissek). W roku 2008 nastąpił ,wysyp” gmin z podwójnymi nazwami miejscowości na terenie województwa opolskiego, gdyż podwójne nazwy wprowadziło 13 gmin, w roku 2009 kolejnych 5 gmin, a w roku 2010 kolejne 4 gminy. Pierwsze podwójne nazwy miejscowości na terenie województwa śląskiego zostały wprowadzone w dniu 22 grudnia 2006 roku na terenie gminy Radłów. Aktualnie ${ }^{21}$ na terenie województw śląskiego wprowadzono podwójne nazwy na terenie 6 miejscowości znajdujących się w dwóch gminach (Rudnik, Krzanowice).

Obecnie na terenie Polski 798 miejscowości posiada podwójne nazwy. Najwięcej, bo 397 z podwójnymi (polskimi i kaszubskimi) nazwami występuje na terenie województwa pomorskiego, drugim województwem jest opolskie z liczbą 333 miejscowości z podwójnymi nazwami (polskimi i niemieckimi). Jest to znaczący przyrost w stosunku do liczby takich miejscowości, które spełniały ustawowy zapis $\mathrm{w}$ wyniku danych pochodzących ze spisu $\mathrm{z}$ roku 2002.
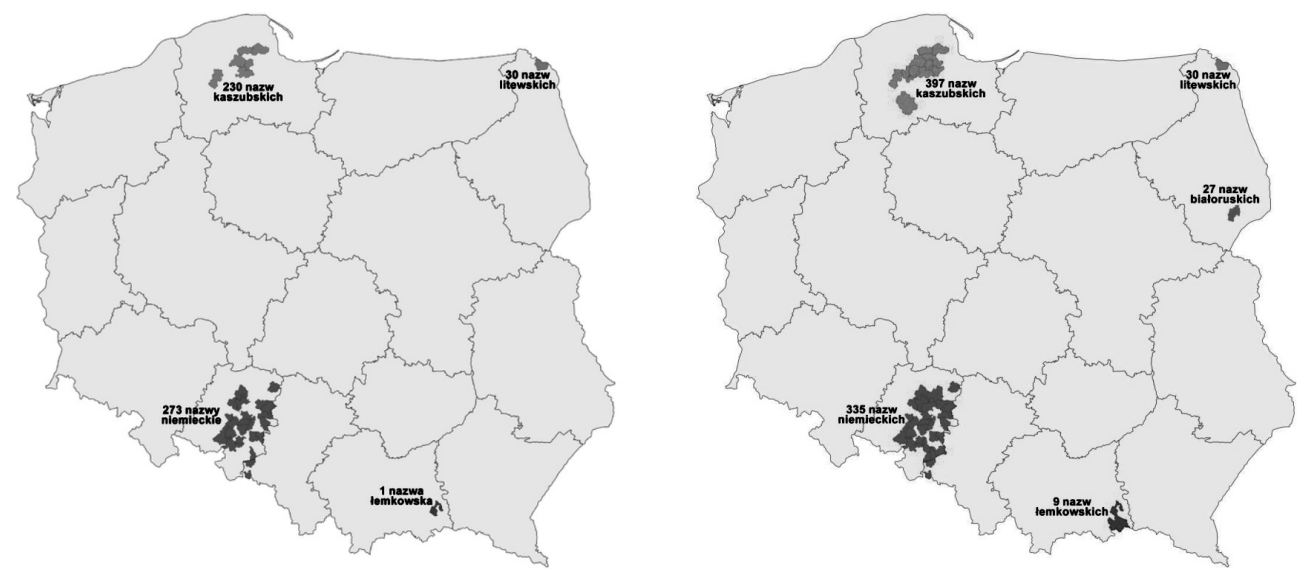

Mapa 3. Gminy w Polsce, które wprowadziły podwójne nazwy miejscowości na podstawie danych pochodzących z Narodowych Spisów Powszechnych pochodzących z lat 2002 i 2011

Źródlo: http://pl.wikipedia.org/wiki/Plik:Gminy_z_dodatkowymi_nazwami.png\#filehistory, 10.05.2010; http://pl.wikipedia.org/wiki/Plik:Gminy_z_dodatkowymi_nazwami.png\#filehistory, 20.04.2013.

${ }^{20}$ E. Miś, Endlich ein multinationales Polen, „Schlesisches Wochenblatt” z dnia 14-20 stycznia 2005 r.

${ }^{21}$ Dane z dnia 8 marca 2012 r. 
Kolejnym etapem tego procesu było pojawienie się na trzech stacjach kolejowych w gminie Chrzastowice, na trasie Opole-Kolonowskie, niemieckich nazw, co podobnie jak w przypadku wprowadzenia podwójnych nazw na tablicach drogowych, wywołało niechętną reakcję ze strony środowisk narodowych. Jednak argumentacja przeciw jak dotąd nie ma wydźwięku politycznego, lecz przeciwnicy wprowadzenia tych nazw odwołują się głównie do argumentów natury ekonomicznej ${ }^{22}$.

\section{Konkluzje}

Początkowo wprowadzenie w życie zapisów ustawy wywoływało sprzeciw ze strony polskich mieszkańców tych miejscowości, którzy wspierani byli przez przedstawicieli środowisk nacjonalistycznych. Najczęściej formułowanymi argumentami przeciw były argumenty mówiące o tym, że:

- w Polsce nie ma mniejszości narodowych i etnicznych, a ci którzy określają się jako nie Polacy, to gracze polityczni;

— istniejące rozwiązania prawne w sposób dostateczny regulują potrzeby tych grup;

- ustawa będzie początkiem demontażu państwa polskiego;

- państwa polskiego nie stać na wprowadzenie w życie tak kosztownej ustawy.

Wydaje się, że obecnie doszło do uspokojenia nastrojów i problem ten nie wywołuje jakichś długotrwałych napięć między ludnością polską i niemiecką. W ocenie przedstawicieli mniejszości narodowych i etnicznych tablice były najbardziej spektakularnym wydarzeniem w procesie uświadamiania społeczeństwu polskiemu istnienia mniejszości niemieckiej i mają wymiar symboliczny, podobnie rzecz się ma z wprowadzeniem języka niemieckiego do urzędów jako języka pomocniczego, gdyż w ten sposób język ten zyskuje na terenie Rzeczypospolitej Polskiej status języka urzędowego. Drugim etapem oswajania społeczeństwa polskiego z niemieckością na terenie Śląska Opolskiego zdaniem uczestników XIII Seminarium Śląskiego, które odbyło się w dniach 29.09-4.10.2010 w Kamieniu Śląskim pod nazwą „Języki Ślązaków, wczoraj, dzisiaj, jutro", miał być powrót napisów historycznych na pomniki. Jednak z uwagi na fakt, że często były to napisy z okresu 1933-1945, to uczestnicy seminarium wskazywali, że może to rodzić konflikty, podobne do tych, jakie wywołało wprowadzanie podwójnych nazw miejscowości. Kolejnymi etapami wprowadzania dwujęzyczności na terenach zamieszkałych przez mniejszość niemiecką miało być wprowadzenie dwujęzycznych nazw instytucji publicznych, dwujęzycznych oznaczeń stacji kolejowych przystanków autobusowych. Jednak zadaniem najważniejszym było, i nadal jest, upowszechnienie nauki języka niemieckiego poprzez zwiększanie liczby dwujęzycznych szkół, które mają wypełnić najważniejszą lukę, to znaczy znacząco poprawić znajomość języka niemieckiego wśród najmłodszego pokolenia mniejszości niemieckiej.

Nadal najbardziej aktualne są postulaty dotyczące informowania społeczeństwa polskiego o problemach, z którymi boryka się mniejszość niemiecka w Polsce. Do osiągnięcia tego celu powinno przyczynić się, uruchomienie niemieckojęzycznej rozgłośni radiowej w Opolu, zwiększenie informacji na temat problemów mniejszości w polskich i niemieckich mediach publicznych, rozciągnięcie zapisów o stosowaniu języka pomocniczego z poziomu gminy na poziom powiatowy i wojewódzki, wprowadzenie do programu nauczania szkół polskich pro-

${ }^{22}$ K. Świerc, Chrzastowice - pierwsza gmina w kraju, „Wochenblatt.pl” z dnia 16-22 listopada 2012 r. 
blematyki związanej z istnieniem mniejszości etnicznych i narodowych w Polsce. Jednym z najbardziej kontrowersyjnych postulatów formułowanych przez liderów mniejszości niemieckiej jest oczekiwanie zmiany interpretacji przebiegu i wyników zarówno plebiscytu górnośląskiego, jak i powstań śląskich. Istota zmian dotyczyć ma ukazywania tych wydarzeń nie jako przejawu polskich zrywów narodowych, a raczej jako przejawów tragicznej wojny domowej, której ofiarami byli głównie Górnoślązacy. Jeszcze innym postulatem formułowanym przez liderów mniejszości niemieckiej jest postulat dotyczący zintensyfikowania badań socjologicznych nad fenomenem mniejszości niemieckiej w Polsce. Mniejszość niemiecka oczekuje również odstąpienia od zasady wzajemności, czyli od zasady, w myśl której rozwiązania względem mniejszości niemieckiej w Polsce miałyby być stosowane wobec Polaków mieszkających w Niemczech nazywanych przez orędowników tego rozwiązania mniejszością polską w Niemczech, z czym liderzy mniejszości niemieckiej się nie zgadzają, argumentując, że inna jest geneza diaspory polskiej w Niemczech, a inna mniejszości niemieckiej. Wprowadzenie tej zasady mogłoby w istotny sposób ograniczyć uprawnienia mniejszości dotyczące korzystania ze wsparcia prawnego i finansowego ze strony państwa polskiego.

\section{Bibliografia}

Choroś M., Jarczak Ł., Niemieckie elementy w nazwach miejscowych, w: Wokót niemieckiego dziedzictwa kulturowego na Ziemiach Zachodnich i Pólnocnych, red. Zb. Mazur, Poznań 1997.

Dobrowolski W., Ślub po niemiecku, „Schlesisches Wochenblatt” z dnia 21-27 stycznia 2005 r.

Dobrowolski W., Wójtowie boją się dwujęzycznych tablic, ,Schlesisches Wochenblatt” z dnia 23 grudnia 2005 r. -5 stycznia $2006 \mathrm{r}$.

Kandzia K., Alle sprechen Polnisch, „Schlesisches Wochenblatt” z dnia 6-12 sierpnia 2010 r.

Kandzia K., Drugie Kosowo, „Wochenblatt.pl” z dnia 14-20 grudnia 2012 r.

Kłoskowska A., Kultury narodowe u korzeni, Warszawa 1996.

Miś E., Deutsch im Amt, ,Schlesisches Wochenblatt” z dnia 14-20 stycznia 2005 r.

Miś E., Endlich ein multinationales Polen, „Schlesisches Wochenblatt” z dnia 14-20 stycznia 2005 r.

Miś E., Quo vadis, mniejszości niemiecka w Polsce?, „Dialog” 2009, nr 87.

Nijakowski L. M., Domeny symboliczne. Konflikty narodowe i etniczne $w$ wymiarze symbolicznym, Warszawa 2006.

Ossowski St., O ojczyźnie i narodzie, rozdział: Zagadnienia więzi regionalnej i więzi narodowej, Warszawa 1984, s. 112.

Przynależność narodowo-etniczna ludności - wyniki spisu ludności i mieszkań 2011, Notatka informacyjna GUS, 29.01.2013.

Radziński R., Szczygielski K., Ślaska ludność rodzima w strukturze demograficznej i społecznej Ślaska Opolskiego wczoraj i dziś, Opole 2008.

Wagińska-Marzec M., Postawy mieszkańców Opolszczyzny wobec podwójnych nazw miejscowości, Poznań 2003.

Wagińska-Marzec M., Spory o nazwy miejscowości na Opolszczyźnie jako syndrom walki o tradycję, „Zeszyty Instytutu Zachodniego" 2002, nr 27, Poznań 2002.

Szmeja M., Niemcy? Polacy? Ślazacy!, Kraków 2000.

Szczygielski K., Geografia mniejszości narodowych i etnicznych w Polsce. Ujęcie ilościowe, Opole 2006.

Świerc K., Chrzastowice - pierwsza gmina w kraju, „Wochenblatt.pl” z dnia 16-22 listopada 2012 r.

Wokót niemieckiego dziedzictwa kulturowego na Ziemiach Zachodnich i Pótnocnych, red. Zb. Mazur, Poznań 1997. 


\title{
Discussions and disputes regarding the introduction of double names for places in the Śląsk Opolski region
}

\begin{abstract}
Summary
The emergence of a German minority in the western part of Śląsk Górny (Upper Silesia, Opolskie Region) in 1989 stirred a discussion, mainly among sociologists and political scientists, on the criteria that would make it possible to solve the issue of justifying this minority's presence in Poland. At the same time, the leaders of those minority circles faced the task of demonstrating that they were German in ethnic and cultural terms. For both parties it became important to force the Polish Parliament to pass a "minority law" as it came to be called. The battle for the provisions of this act, with varying intensity, lasted until January 2005, when it was signed by the President of Poland and the law entered into force in May of the same year. The adoption of the law on ethnic and national minorities and regional languages enabled minorities to introduce double naming of places where they reside. Initially, this phenomenon was most intense in the Opole part of Górny Ślask triggering a full range of reactions, ranging from the definitely hostile, threatening an outbreak of an ethnic conflict, to treating this phenomenon as an element enhancing the socio-cultural attractiveness of regions inhabited by minorities.
\end{abstract}

